found. Such inclusions were reported previously to be present in a cultivated sample of this species ${ }^{2}$. No spindles have been found in pads of twenty cactus species examined shortly after field collection in Arizona, California and Montana.

In all cases, virus transmission was successful, as judged by the development of spindles, when sap from spindle-containing specimens was injected into or rubbed on the previously spindle-free pads of Opuntia species growing in the Montana State University greenhouse and the University of California at Los Angeles Botanical Garden.

No external symptoms appeared when representatives from the families Leguminosae, Solanaceae, Chenopodiaceae, Cruciferae, Tropaeolaceae or Cucurbitaceae were inoculated. Electron micrographs made from spindle-containing pads by the quick-dip method $^{3}$ showed two groups of elongated particles, with one length peak at $515 \mathrm{~m} \mu$ (similar to cactus virus 1 (ref. 4)) and another at $300 \mathrm{~m} \mu$.

We wish to thank H. O. Agrawal and R. A. Solberg for help with some experiments, and Dr. L. Bos for the electron microscopy. This work was supported by the U.S. Public Health Service Grant No. E-596(c).

(The late) Irene M. Sammons M. Chessin

Department of Botany,

Montana State University, Missoula, Montana.

${ }^{1}$ Molisch, H., Ber. Deutsch. Bot. Ges., 3, 195 (1885).

Amelunxen, F., Protoplasma, 49, 140 (1958)

${ }^{3}$ Brandes, J., Nachrbl. deut. Pflanzenschutzdienst (Braunschweig), 9, 151 (1957)

4 Brandes, J., and Wetter, C., Virology, 8, 99 (1959).

\section{Antimicrobial Substances from Ferns}

Ir has been almost twenty years since Osborn ${ }^{1}$ reported his now classical work on antimicrobial substances from green plants. Since that time the literature accumulated on this subject has been voluminous ${ }^{2}$. The vascular plants tested, however, have been essentially spermatophytes, with little attention to the pteridophytes. This work is concerned with the extraction of antimicrobial substances from thirty ferns collected at the Brooklyn Botanical Gardens. The specimens were selected at random. and the cut fronds were allowed to dry in air for at least one week before testing. Four additional dried ferns were obtained from other sources and likewise tested.

Extracts of the plants were prepared in the following manner: $15 \mathrm{gm}$. of pulverized material were added to $100 \mathrm{ml}$. of methanol and macerated in a Waring blendor for $3 \mathrm{~min}$. and filtered. Filter-paper disks $(6.35 \mathrm{~mm}$. diam.) were saturated with the extract and allowed to dry for $3 \mathrm{hr}$. The surface of nutrient agar dishes was seeded with $0.5 \mathrm{ml}$. of a $48 \mathrm{hr}$. bacterial broth culture while $0.5 \mathrm{ml}$. of a oneweek-old fungal culture was used to seed Sabauraud maltose agar dishes. The prepared disks were placed on the surface of the seeded dishes and incubated. All micro-organisms were incubated for $48 \mathrm{hr}$., the bacteria at $37^{\circ} \mathrm{C}$., the fungi and Erwinia caratovora at $22^{\circ} \mathrm{C}$. The zones of inhibition were measured from the disk edge to the zone edge and recorded in $\mathrm{mm}$.

In Table 1 is listed the ferns and their zones of inhibition against 8 bacteria. No zones of inhibition were produced against Aspergillus niger ATCC 6277, Candida albicans ATCC 10231, Gibberella fugikuroi

$$
\begin{aligned}
& \text { Table 1. ANTIBacterial Propkrties of FerNS } \\
& \text { Cyatheaceae } \\
& \text { Alsophila cooperi } \\
& \text { Cibotium glaucum }
\end{aligned}
$$

NRRL 2284, and Helminthosporium trucicum ATCC 11535. The results indicate that antibacterial substances were extracted in the methanol-soluble fraction from 33 of the 34 specimens tested and that plant pathogenic bacteria are more susceptible than human pathogens. This may perhaps explain the relative resistance of ferns to bacterial invaders. Additional extracts are being prepared in this Laboratory and will be the subject of future reports.

Biology Department,

JASPER C. MARUZzella

Long Island University,

Brooklyn, New York.

'Osborn, E. M., Brit. J. Exp. Pathol., 24, 227 (1943).

${ }^{2}$ Nickell, G. L., Econ. Bot., 18, 281 (1959).

\section{Introduction of the Potato into Western and Central Europe}

The botanist Clusius, who prepared one of the first descriptions of the potato plant ${ }^{1}$, indicated not only the time (the beginning of 1588) of his receiving from Philippe de Sivry (Prefect of the City of Mons, Belgium) two potato tubers and a berry, but also when Philippe de Sivry himself obtained the tubers. Clusius wrote that Philippe de Sivry had received it in the preceding year from a certain friend of the Papal Legate in Belgium under the name of 'Taratouffli'. ("Is a familiari quodam Legati Pontifici in Belgio se 